\title{
'A little of what you fancy': Love, marriage and other social problems
}

I am a girl what's a-doing very well in the wegetable line

And as I'd saved a bob or two, I thought I'd cut a shine

So I goes and buys some toggery, these "ere wery clothes you see

And with the money I had left, I thought I'd have a spree

So I goes into a Music Hall, where I'd often been afore

I don't go in the gallery, but on the bottom floor

I sits down by the chairman, and calls for a pot of stout

My pals in the gallery, spotted me, and they all commenced to shout.

Bessie Bellwood, 'What Cheer, 'Ria'

MUSIC HALL WAS the business of pleasure. Its prime functions were to entertain and to generate profits. Lyricists were largely interested in writing hit songs, not providing incisive social commentary. Performers saw themselves as entertainers not educationalists. However, the subject matter of many songs related directly to a range of mundane social and economic issues and the way in which they were treated provide insights, wittingly or otherwise, into contemporary attitudes. Many of the songs dealing with love and marriage were conventional, reflecting the dominant values of a patriarchal society in 
which the family was seen as the bedrock of morality and social stability. Although harsher realities intruded at times, the threat they posed was often diffused through humour. Further, the treatment of social problems, while evoking sympathy for individual victims, never explicitly challenged the social and economic order that gave rise to them; nor those who defended that order. In contrast to melodrama, music-hall song tended to be sympathetic towards the police, laughing at their human weaknesses for food and fair damsels but rarely criticising the way in which they went about their work.

\section{Love and marriage}

Love, marriage and family featured in numerous songs, though the treatment could vary considerably. While often seen as 'eternal' themes, the songs need to be understood in a more specific late-nineteenth century context in which 'natural' gender roles and institutions, in the minds of many, were being questioned, even undermined. The 'New Woman,' seeking independence, education, professional employment and even the vote was a contentious figure. Equally, if less publicised, the middle-class male 'flight from domesticity' appeared to cast doubt on an institution once seen as natural and Godgiven. ${ }^{1}$ Music-hall songs celebrating love and marriage were generally conservative, upholding marriage and a 'separate spheres' ideology. This does not mean that every love song was an explicit comment. Joe Wilson's 'Sally Wheatley' was a sorrowful tale of missed opportunity and lost love. George Leybourne's 'Sarah's Gone And Left Me' comically bemoaned the sorry plight of 'a sandwich man' whose love for the eponymous Sarah, a nursemaid, is thwarted by the dastardly cat-meat man, who seduces her with a half-price skewer of meat. ${ }^{2}$ Nonetheless, there was a general assumption that love would lead to marriage and a family life.

Love was often seen in romantic terms, foreshadowing the American popular songs of the 1920s and 1930s. In 'Love is a Mystery. Love is a Dream,' Albert Chevalier sang 'Love is romantic whatever may be said' and 'Love is the essence of life that we live.' Courtship could have its moments of harmless 'spooning', but marriage was the 'natural' outcome, even if early encounters were fun. Following 'a charming game of 
croquet,' Arthur Lloyd discovered 'it's naughty but it's nice,' only to find himself on the brink of matrimony within four verses. Women echoed these sentiments, though at times more whimsically. Daisy Dormer declared:

Ain' it nice when he offers you a poppy

Ain' it nice when he looks at you so sloppy?

Ain' it nice when you're squeezing in the doorway

Ain' it nice though it's colder far than Norway?'

The outcomes were predictable. 'Soon the bells, wedding bells, ring ding, dong/ Man and wife, tied for life, good and strong'.

Within the family, generally speaking, mothers were seen in a positive, if sentimentalised, light, captured in Gus Elen's 'Coster Muvver.' Looking upward, pointing to heaven with cap screwed tightly in hand, he delivered a tear-jerking chorus.

She's just the sort a muvver that a bloke wants, eh! Ah, when she's took'd away I won't feel wery gay, As far as me and 'eaven's concern'd I don't put on no side,

But if muvver ain't a-goin' in, well this bloke stops outside.

Other songs, like 'Mother's Advice,' were more light-hearted, but even here mother as font of knowledge and support was the underlying message. Fathers in comparison, were painted less favourably. Some were lazy, as in 'We All Go to Work but Father,' others incompetent, as in 'When Father Laid the Carpet on the Stairs' or 'When Father Papered the Parlour.' Almost without exception, they were dependent on their wives. In 'Skylark, Skylark,' Arthur Lennard's 'dear little boy' pleaded with the skylark:'If among the angels mother you see/ Ask her if she will come down again/ To poor dear Daddy and me.' ${ }^{4}$ Such sentiments chime with the observations of people like Robert Roberts, who emphasised the central role that women played in working-class society, but they also provided a comic cover for patriarchal authority, by ridiculing individuals who failed to 'be a man.' 
Marriage was eulogised, as in Katie Lawrence's 'My Old Man' with its chorus:

My old man! My dear old man!

Best in the world since the world began.

In joy and tears,

Through forty years,

Always true and faithful to me, my old man. ${ }^{5}$

Georgina Leonard's 'Shadows on the Blind' paid tribute to a long and successful marriage, but couched in unambiguously patriarchal terms with its image of an old couple: 'Fifty years they've pulled together since their love tales first were told/ $\mathrm{He}$ is proud to love and cherish and his will she still obeys,' a sentiment given more lasting form in 'Silver Threads Among the Gold.' Marriage and family were brought together in idealised form by both Ella Retford and Daisy Dormer in 'I Want a Girl Just Like the Girl that Married Dear Old Dad.' Even in the light-hearted, 'When I Prove False to Thee,' - at which time, according to Arthur Lloyd, 'the tide shall cease its flowing' and 'the cocks will stop their crowing' - the underlying sentiment is of undying love.

Enduring love in the form of the devoted couple appear regularly. Even in Jenny Hill's harsh world the 'aged couple [who] have drifted downwards, been of all bereft' still have their love. 'Death alone can part faithful heart from heart.' In more sentimental manner, Albert Chevalier was hugely successful with 'My Old Dutch.'

Sweet fine old gal,

For worlds I wouldn't lose 'er,

She's a dear good old gal,

An' that's what made me choose 'er.

She's stuck to me through thick and thin,

When luck was out, when luck was in,

Ahl wot a wife to me she's been, An' wot a pal!

Marriage was not always seen in positive terms. Several songs warned against it in variations of the traditional 'When I was 
single' complaint. In some men were trapped - 'She was one of the early birds and I was one of the worms.' More often women were the victims. 'Girls of today ... don't realise how deceitful men are,' according to Vesta Victoria. Jennie Hill, 'the Vital Spark,' was among the most pessimistic. ${ }^{6}$ A hugely successful and wonderfully exuberant performer, noted as much for her dancing as her singing, Hill portrayed a range of characters over the course of her career but much of her act focused on the lives of working-class women. The procession of downtrodden mothers and disillusioned wives combined with the unambiguously titled, though unpublished songs, such as 'I've Been A Good Woman to You,' 'Who'd Be A Mother,' 'Woe Is The Mother Who Owns Eleven' and 'A Woman's Work Is Never Done' made clear the harsh realities of working-class married life.7 Although some critics dismissed 'I've Been A Good Woman To You' as 'inconsequential and self-satisfied,' other reports speak of the 'general and fervent expressions of admiration' called forth by her characterisation of a fierce, if lachrymose wife. ${ }^{8}$ Similarly, her rendition of 'I'm Determined No LongerTo Stand It.' at London's Royal music-hall, was 'very warmly applauded.9 Some songs hinted at acts of resistance. Hill was not averse to threatening various dreadful things with a rolling pin to her 'wicked and disobedient husband' but, in another song, she made clear, more radically, that she 'mean[s] to have a legal separation. ${ }^{10}$

Others seemed to subvert convention through role reversal. Florrie Forde's 'Good Little Wife' was well in control of her husband. 'She calls him her 'honey' and spends all his money/ Like a good little wife should do.' Moreover, 'She makes him sift cinders and clean all the winders/Like a good little wife should do. "The hen-pecked husband was a figure of fun, reminiscent of a Bamforth post-card, as in 'Just to Show Who Was Boss in The House.' Having been told his wife wears the trousers, Jack Pleasant's character, seeks to prove otherwise:

Just to show who was the boss of the house

I went and I washed all the clothes

I scrubbed all the pans and I cleaned all the mugs

I made all the beds and filled all the jugs

I didn't get finished till evening 
Then she started my temper to rouse

So I went and did the place over again

Just to show who was the boss of the house.

Such 'comedy' songs, again, strengthened the belief that the man should be in charge by ridiculing the one who was not. Also, they could disguise a more sinister reality domestic violence. The scandal of 'wife-beating' was a cause for concern for a small number of social reformers, who often highlighted working-class barbarity, especially in the so-called 'kicking districts' of north-west England. Popular attitudes were less straightforward. Court records reveal the prevalence of violence against women, and also a general acceptance of the need for and acceptability of male-applied discipline. The right to chastise wives, children and servants, went largely unchallenged. Only when it was taken too far was there a popular outcry. ${ }^{11}$ Domestic violence appeared in various forms of popular culture. Melodrama lent itself more readily to serious consideration but even here domestic violence was often seen simply as the result of drunkenness. In comparison, music hall rarely addressed the question directly. However, there was unwitting testimony, notably in one of the most popular songs around the turn of the twentieth century.

Gus Elen's 'It's A Great Big Shame,' with its sub-title, 'I'm Blowed If 'E Can Call 'Isself 'Is Own,' is often cited as a humorous song, lamenting the fate of a hen-pecked husband. It is the story of a (supposedly) proper man emasculated by a diminutive, shrew-like wife of four foot two. Jim, his 'pal ... as 'ad ter 'nuckle dahn [despite being] a brewer's drayman, wiva leg of mutton fist.' His physical strength ('It took two coppers for ter make 'im move along/ An annuver six to 'old the feller dahn') is contrasted with the demeaning tasks (cleaning windows and knives, scrubbing floors and 'wiv a apron on 'im on 'is knees a-rubbin' up the old 'arf-stone') that he has been forced to do. The chorus, which contains the ominous words 'an' if she belong'd ter me, I'd let 'er know who's who,' was accompanied by on-stage actions, caught on camera in the early 1930s, that made clear that the solution lies in firm, physical action, The song was reputedly a favourite among men in the gallery. ${ }^{12}$ It proved immensely popular for 
Elen and was also sung (and parodied) by men and women across the country in a wide variety of venues. Era, which described the song as a 'classic,' praised its 'lighter vein' with its 'savage lamentations at the miserable fate of Drayman Jim ... [and his] hymeneal martyrdom. ${ }^{13}$ Only the Pall Mall Gazette 'grumbled,' taking exception to 'the introduction of the very material coke-hammer to emphasize his sentiments' on the grounds that Elen's comedic skills were such that he did not need 'such extraneous aids. ${ }^{14}$

Domestic violence also appears in Marie Lloyd's 'It's A Bit of Ruin That Cromwell Knocked About A Bit.' The first chorus opens 'it's a bit of a ruin' but concludes with the singer confessing: 'Outside the Oliver Cromwell last Saturday night, I was one of the ruins Cromwell knocked about a bit.' Subsequent choruses retained the final lines but opened 'I'm one of the ruins ...' Lloyd's turbulent marriage with Alec Hurley was well-known and few in the audience could have been unaware of the references. Indeed, many of Lloyd's later songs were wistful reflections on the plight of the older woman - 'You're A Thing of The Past, Old Dear' and 'I Live in Hopes' ${ }^{15}$ - though none referenced violence directly.Violence also figured in Dan Leno's 'My Old Man.' Recounted by the wife, 'ten years ... a wedded martyr,' who, having fallen for the rosy image of marriage, finds 'that matrimony means black eyes and broken noses, [while] bread and cheese is flavoured with a hob-nailed boot.' Disillusionment set in for 'not a week had we been wed, when he punched me in the head,' and 'As years go on his love for me decreases, But I'll make him suffer sure as eggs are eggs' and in the final chorus violence begets violence: 'as sure as I'm his wife, this night I'll have his life.'

Such songs, however, were the exception. Insofar as marriage was problematic, the issues were diffused via humour - as in 'Whit Cunliffe's 'The Matrimonial Handicap' - but also used to reinforce conventional morality. In Arthur Lloyd's 'German Band' the wife runs off with a strolling flautist, only to be abandoned and reduced to 'charring for a shilling a day.' The implicit (and conservative) message, that those who flaunt marriage are duly punished, is clear. Similarly, in Vesta Tilley's 'The Parson and The Cook', the errant cook, canoodling with the parson Jones, is sacked and the parson suffers the indignity 
of having his hair and whiskers torn. Generally speaking, errant husbands get off lightly. The various male miscreants, husbands at work or fathers in 'gay Paree,' when caught out, are exhorted only to 'Hold Your Hand Out, You Naughty Boy.' In the 1913 song, 'Don't Say a Word to the Wife,' the matter is swept under the carpet. The philandering Peter Henry seduces a girl in Brighton and, on being told he is 'the father of a fine boy,' responds in the words of the song title and explains 'there'll be trouble waiting for me if she hears about it [because] ... If she finds out, you see, she'll put all the blame on me.' So "sh not a word to the wife.'

\section{Social problems}

The wider economic context, employment and its insecurities, poverty and the threat of destitution were a staple of popular culture in general. Again, melodrama lent itself more readily to treating such problems. Certain theatres, such as the Britannia, conscious of their neighbourhood audiences, offered a range of social commentary plays including Work Girls of London, London by Night; The Streets of London; The Casual Ward; and The Artificial Flower-makers. ${ }^{16}$ It was easy to criticise their simplistic and conservative critiques. ${ }^{17}$ As Era, in a review of Sons of the Forge, commented: 'a hero drawn from the poorer classes and the villain of the piece from the 'bloated aristocracy' will always furnish a palatable drama for an East End audience.' ${ }^{18}$ However, there was a strong sense of injustice and a belief that society should be run on moral lines.

Music hall also featured 'social problems,' but many issues were diluted and defused through humour.The tensions created by living cheek by jowl in overcrowded rooms are treated in light-hearted fashion in three of Joe Wilson's songs: 'The Neebors Daan Belaw, 'The Row on the Stairs' and especially, 'Keep Yor Feet Still! Geordie Hinny' Similarly, the wellknown, 'Cock Linnet Song,'(aka 'My Old Man') dealt with a very real problem (the inability to pay the rent) and a common response (a moonlight flit) but the humour of the words, and the catchiness of the tune, could detract from the seriousness of the situation. It contrasts with the more realistic but dour, temperance-inspired, 'Father, Dear Father, The Brokers Are In,' which laments the fate of starving mother and children 
while father drank away his wages. Albert Chevalier in 'The Jeerusalem's Dead' similarly reduces a major economic blow to any costermonger, the death of his donkey, to something comic. ${ }^{19}$ Even accidental deaths, at home and at work, could be given a (grim) humorous twist. As the chorus of 'More Work For the Undertaker' made clear such unfortunate mishaps led to: 'More work for the Undertaker/ Another little job for the tombstone maker.'

Occasionally, the humour barely masked a more serious comment. The Pawnshop Bleezin" with its jaunty tune appears initially to be comic. Based on a real incident, the destruction of Trotter's pawnshop in Newcastle in 1849, the song appears to be a humorous description of the chaos following the fire. The detail paints a different picture of anguish.

The wimmin folk 'twas sair to see Lamentin' their distresses For mony a goon, an' white shemee, Was burnt wi' bairns' dresses.

And reveals a range of underlying problems:

An' when wor Billy finds it oot, There'll murder be, aw hae nee doot; Oh dear! What garr'd me put them in? 'Twas a' the races an' cursed gin That set my claes a-bleezin'

Before concluding:

The world was better far aw'm sure When Pawnshops had ne neym, man; When poor folks could their breed procure, Without a deed o' sheym, man.

At a time when the London poor were coming under scrutiny, from the investigative journalism of G R Sims to the more scientific research of Charles Booth, some songs cast (or appeared to cast) an eye on the realities of the streets. A common device was to have an observer in a specific location 
or institution who detailed the characters before them. In 'One of The Sights of London' Arthur Lennard noted the coexistence of wealth and poverty. The 'gilded youths' around St James' contrast with the orphaned coster boy.

He's one of the mites of London

Cruel old London Town

Many the mites you view as you

Go strolling up and down

Starving amid the splendour, tortured by hunger's

blights

There's no one to help him, no mother to love

One of London's poor little mites.

In Jenny Hill's 'Thereby Hangs A Tale,'the narrator is a stowaway, who catalogues a sorry parade of doss house characters down on their luck, the one-time lawyer, the married couple who have lost all, and especially 'Crazy Sal.'

Muttering in a corner o'er a crust of bread

Crazy Sal they call her, sits with palsied head

Hear her dreary laughter, see her skinny hands

As the drink fiends gather round in grissly bands

Hear her shriek and say, 'Devils get away

Look how they laugh and grin, Oh for God's sake,

Gin, ${ }^{20}$

The common theme is people down on their luck and reduced to poverty, though no back story is provided, and the implicit moral is not to judge by appearances. The same theme emerges from her highly popular, 'City Waif,' though this time there are more of the street folk noted by Sims or Mayhew. The watercress seller, Sal Brown, is probably a prostitute ('some say she ain't no better, ain't Sal, than she ought to be/ P'raps she ain't, p'raps she is) but she saves the life of the waif's crippled sister. The refrain drives home the message. 
Then up comes Sal Brown at that moment and, rough as she is - says she

'Take this money, here. Run for food boy.'Then she took Kitty on her knee

She saved the life of my sister, and though people run her down

She played an angel's part, that night, in the streets of London Town.

These songs held up a partial picture of street life. They exhibit sympathy for victims, especially deserving figures such as the orphaned child, but there is little overt criticism of the existing socio-economic circumstances that created the problems. Insofar as solutions are offered, they tend to be couched in terms of individual decency. As the title of G W Hunter song exhorted, 'Give What You Can to Those in Distress.'

There was also a sense of fatalism, as in songs like 'Life Is Like A Game of Seesaw,' which ran alongside an emphasis on self-reliance as in 'A Motto for Every Man' with its chorus:

So we will sing and banish melancholy

Trouble may come; we'll do the best we can

To drive care away, for grieving is a folly

Put your shoulder to the wheel is a motto for every man.

The titles of two of Harry Clifton's motto songs, 'Paddle Your Own Canoe' and 'Work Boy, Work and Be Contented' encapsulate this mentality. The chorus of the latter was unambiguous in its naive faith in hard work:

So work boys work and be contented

As long as you've enough to buy a meal.

The man you may rely, will be wealthy by and bye,

If he'll only put his shoulder to the wheel.

Scarcely more sympathetic was Gus Elen's 'Wait Till the Work Comes Round.' The song title and the opening lines of the chorus appear to combine sympathy and fatalism: 'What's the use of kicking up a row/ If there ain't no work about? But, 
as the scene in which he appeared on stage made clear, there was little sympathy for the unemployed. A tatty room, dirty crockery and empty beer bottles met the eye and the scene was entitled 'The Wrong-Un's Bedroom at noon.' At a time when the plight of the unemployed was a major political issue, there is little sympathy for the idea that one should 'wait till the work comes round.' Such is the burden of the song that the humour in the chorus does not ask the audience to identify with such sentiments as 'lay your head back on yer piller and read yer 'Daily Mirrer,' let alone the claim ' if you can't get work you can't get the sack/That's a argyment that's sensible and sound.' But some in the audience might have taken a different view, sharing the sentiments in W P Dempsey's parody, 'Work and Be Contented.'

Now you don't require a job, to obtain the merry bob, As frequently I fancy it's been shown;

Many Artful Codgers thrive and by hook or crook survive

To obtain a decent living on their own.

In the light-fingered trade there's a fortune to be made,

Provided you are smart as well as quick,

And altho' it's not allowed, when you're mixed up in a crowd,

And you see any pockets there to pick.

There were some other important exceptions. Ned Corvan's 'Sweating System' made clear that 'working men are still opprest,' while Joe Wilson's 'Ne Wark' paints a stark picture of the unemployed: 'What wretchedness, what misery' The stark lyrics of the latter contrast with the jauntiness of the tune, 'Pretty Polly Perkins,' to which it is set. Both men drew attention to the problems facing colliers. The physical dangers were highlighted in 'In Memory of the Hartley Catastrophe' and 'Perils of the Mine, or the Collier's Death.' Poverty-driven emigration was the subject of 'Astrilly' or the Pitman's Farewell. ${ }^{21}$ 
Aw mind the time when collier lads cud work for goold at hyem, man:

Dash! Aw mind the time when collier lads cud spend a pund each day;

But noo the times thoor queer, man, we've nowther sangs nor cheers, man;

When we cannit raise wor beer, man, it's time te gan away.

The social order, as much as the economic, was also generally viewed conservatively. While the desire for a lucky break never disappeared - that wish to be 'The Man Who Broke the Bank at Monte Carlo' - people with pretensions, living above their station were either ridiculed or condemned. With their new donkey shay, following the death of 'rich Uncle Tom of Camberwell, the central couple in 'Knocked 'Em In The Old Kent Road,' are figures of fun because they think of themselves 'carriage folk ... like the toffs as rides in Rotten Row.' More savage is the critique in ' $E$ Dunno Where 'E Are.' Market trader Jack Jones is another beneficiary of a will but this time his pretensions lead to isolation. ${ }^{22}$

When I see the way 'e treats old pals

I am filled wiv nothing but disgust

'E sez as 'ow we isn't class enuf

'E sez we ain't upon a par.

Smoking a cigar rather than a pipe, and 'wiv a top 'at on,' he ends up 'drinking Scotch and Soda on his own.' There was a 'natural' social order that to challenge was a risk.

The 'natural' gender roles of men and women were reinforced in many songs, but some performers challenged these assumptions. As Jenny Hill established herself as a major music-hall serio-comedienne in the 1870 s, her repertoire contained a number of songs that challenged the position of men. So alongside songs, such as 'I'll Meet You Love Along the Line' and 'The Boy in the Gallery', which were conventional love songs, she also sang 'Bother the Men,' 'A Fig for Men' and 'I'm Determined To No Longer Stand It.' 'Bother the Men' was originally a song performed by Mrs Howard Paul that made 
fun of advocates of rights for women. She appeared as 'Miss GRYM' to deliver a 'RED HOT LECTURE ON WOMAN'S RIGHTS. ${ }^{23}$ Jenny Hill's character, Miss Grym, appeared to be similar - an old maid to be laughed at whose arguments were nonsense - but her performances were somewhat different. ${ }^{24}$ At the London Pavilion in January 1872, as well as singing the song, she "upheld the rights of women and advocated their claim to wear the breeches.' Furthermore, 'the Chairman, at whom she levelled many of her remarks had rather a bad time of it. ${ }^{25}$ This was not an isolated incident and these outbursts enabled her to create 'an opportunity for her working-class female audience to enjoy hearing abuse leveled [sic] at men as well as the middle-classes. ${ }^{26}$ Later in her career Hill also commented on the contentious issue of women's education. Unlike several of her songs, this was published, suggesting that the lyrics were less likely to offend. The chorus appears to be a conservative rejection of the notion of extending female education.

I don't believe in teaching girls

Such trouble as the Rule of Three.

If they only know their Ps and Qs

They can do without your ABC.

However, her patter in performance puts things in a different light. 'Education is becoming a terrible nuisance - all the girls are getting to be such wonderful scholars that there'll soon be nothing left for men to teach us - not that they ever could teach us much, poor wretches. ${ }^{27}$

Elsewhere, progressive women were treated less sympathetically. 'Happy' Fanny Field's 'The Suffragette' views 'men as simply worms' and will 'put the whole world out of joint' to get the vote. ${ }^{28}$ Even more scathing, Jock Mills in 'The Suffragee' had no doubt that the patriarchal order was under threat. The poor 'downtrodden man' had been reduced to washing and scrubbing since his wife joined 'the Down with Men club.' Her fellow suffragettes were 'mostly old maids laid on the shelf,' and she managed to compound her treasonable and unfeminine behaviour by losing her temper, getting into a fight and being rushed to jail whilst in London protesting. ${ }^{29}$ 
This was not dissimilar from the spate of antifeminist cartoons that ridiculed and vilified advocates of female suffrage.

\section{The Police}

Another topic with strong political connotations was policing. The debate about police reform, from the early nineteenth century onwards, was highly contentious, raising questions about personal liberties and the relationship between the state and the individual. The 'new police,' not just in London, faced suspicion at best, outright hostility at worst. ${ }^{30}$ Despite a crime fighting/thin blue line rhetoric, the bulk of police work was mundane, concerned with establishing and maintaining 'order and decorum' in public places. Increasingly, police work seemed to focus on minor offences, committed overwhelmingly by working-class men, women and children, for whom the streets were the place of work and leisure.

Old and new policemen were to be found in many forms of popular culture but with significant differences of emphasis in their treatment.There was a long tradition of mocking constables, particularly in pantomime. In the first decade of the nineteenth century, at Covent Garden, Grimaldi shut a watchman in his box, stole his lantern and sounded his rattle to create scenes of mayhem in which two buffoonish watchmen mistakenly fight each other, much to the delight of the audience. ${ }^{31}$ The 'bobby' soon became a staple comic character in Victorian pantomime but the humour was generally benign. In the 1871 Crystal Palace pantomime, there was 'a model policeman who is always "on his beat" yet who never "runs anybody in.", 32 Cartoons, notably in Punch, became increasingly affectionate over time. The policeman was something of a clodhopper, but his vices were primarily a liking for beer, on and off duty, and a predilection for food and the cooks who provided it for him on his beat. In contrast, in numerous melodrama the policeman was a villain; maybe not the central villain, but a petty, spiteful figure, whose ill-treatment on stage was seen as 'gratifying and satisfactory.' ${ }^{33}$ As an astute contemporary observer noted, there was genuine distrust and dislike of the police ... behind the hisses and laughter that points the moral for the ridiculously vicious character' on stage. ${ }^{34}$ 
Music-hall, especially in the late-Victorian and Edwardian years, had more in common with pantomime. The clumsy but good-hearted copper, with a weakness for plump cooks and plumper puddings, was very much the image conjured up by Vesta Tilley in 'It's Part of a Policeman's Lot' and 'The New Policeman;' and also in the Great Vance's 'Peter Potts the Peeler' with its chorus:
After goose and rabbit pie
Down area steps a stealer,
Courting cookies on the sly
Goes Peter Potts the Peeler.

Behind the good-natured jokes was a belief in the value of the constable. 'If it wasn't for the police ... what would you do ...Send for a policeman, best thing you can do' sang George Lashwood, while Maud Santley's 1897 song, "The "Bobbies" of the Queen' put the police on a par with 'brave and bold Jack Tars ... Tommy Atkins and our gallant sons of Mars.' To what extent songwriters had an eye to the growing middleclass elements of music-hall audiences is impossible to say, but such songs fitted well with the self-censorship of musichall managements. However, there were some songs which, albeit humorously, painted a far less flattering picture. An early song, 'The New Police Act,' written in 1840 highlighted the pettiness of police action - no squibs or kites, no bell pulling and even no noise on Sundays - but the most scathing critique came in James Fawn's 'Ask a P'liceman.'The charge sheet was extensive. A nod and a wink made it clear why 'every member of the force, has a watch and chain, of course,' lifted from a helpless drunk; but in subsequent verses the critique becomes more explicit:'He'll produce a flowing pot, if the pubs are shut or not;' and 'for advice on rapid flight, ask a p'liceman' before a final nod about his fidelity. ${ }^{35}$ Fawn himself was praised for the accuracy of his characterisation of an ordinary policeman and the song was hugely popular and sung by many singers across the country. Unfortunately, the reviews do not make clear the precise reasons for its popularity, though it is not unreasonable (as with melodrama) to suggest it reflects a deep suspicion of police behaviour. 


\section{Some concluding observations}

Though music hall was more for the people than of the people, especially by the end of the nineteenth century, certain songs addressed readily recognised issues. As with crime ballads discussed earlier, there was a conservative consensus that suggested widely shared attitudes and values. In many instances the approach was one of conservative common-sense - 'Work Boys and Be Contented.' Harsh realities could be sweetened by sentimentality ('My Old Dutch') or defused through humour ('My Old Man') Sympathy could be expressed for 'deserving' victims, without questioning the causes of their misfortunes ('Thereby Hangs A Tale'). The focus on more mundane but commonplace problems, such as finding employment, paying the rent and getting on with neighbours, created a sense of shared experiences, albeit accepted in a stoical manner; but the 'culture of consolation' argument can be overstated. The extent to which the newer, lower middle-class audiences identified with 'doing a moonlight flit' must be open to question. Further, the diversity of the material casts doubt on the validity of a single, overarching interpretation. There were songs of aspiration and inspiration, as much as of consolation and, perhaps more importantly, there were songs that had no profound message but, with their catchy lyrics and rousing and easy to sing choruses, were simply good fun that offered an opportunity to forget, however briefly, the realities of everyday life.

\section{Endnotes}

1 J Tosh, A Man's Place, London, Yale University Press, 1999, has some interesting comments on the 'New Woman' problem as well as the male flight from domesticity.

2 Comical thwarted working-class love was a recurring theme. Harry Clifton's 'broken-hearted milkman' lost his love to 'a bow-legged conductor of a twopenny bus'. Arthur Lloyd's butcher was thwarted by a rival who could offer the eponymous 'American beef.' See also his 'The Organ Grinder'.

3 See EthelVictor's 'Oh! What a wicked young man you are' in which the 'wicked young man' tires of courting and decides to 'settle in life.'

4 In fact, mother did not come down, but her son joined her in heaven that night! Although dead mothers were more common, occasionally a father appeared.The 
bereft son asking, in Denham Harrison's ‘Give Me a Ticket to Heaven' to see his dead father was fortunate to find that he was only in hospital.

5 See also Lily Morris' 'Only a working man,' while the notion of partnership was clear in Florrie Forde's 'Man and wife should pull together' where the coupled literally and metaphorically strove together.

6 J S Bratton, 'Jenny Hill: Sex and Sexism in the Victorian Music Hall' in J S Bratton, ed., Music Hall: Performance and Style, Milton Keynes, Open University Press, 1986, pp.92-110, esp. pp.103-10

7 See for example Era 1 July 1882. The contributor praised her 'excellent' acting as she gave vent to the feelings of 'a poor but clean woman.'

8 Era 1 June 1879 was dismissive of the portrayal of 'a drunken wife' whereas a very positive account of the response to the song was given in Era 4 March 1877

9 Era 23 June 1878.

10 Era 11 February 1882 and 14 May 1881. This was of a piece with earlier songs in which she challenged the supposed superiority of men. See for example 'Bother the men' Era 7 January 1872 and 17 March 1872 for an attack on "what she sneeringly called "the lords of the creation".

11 See M E Doggart, Marriage, Wife-Beating and the Law in Victorian Britain, London, Weidenfield and Nicolson, 1992 and A J Hammerton, Cruelty and Companionship, London, Routledge, 1992

12 It has been claimed that, as well as singing along in full voice, men stood up and imitated Elen's stage actions. See P Norris, A Cockney at Work: The Story of Gus Elen and His Songs, Guildford, Grosvenor House, 2014, p.231-2.

13 Era $8 \& 15$ August and 26 September 1896. It also described the spectacle of 'a big hulking fellow, completely under the control of a little woman' as a 'not uncommon experience.'"7 February 1897

14 Pall Mall Gazette 11 January 1896

15 The song contains the memorable lines - 'For there's a lot of tunes to play on old fiddles they say, So, I live in hope if I die in despair.'

16 J Davis, 'The Gospel of Rags: Melodrama at the Britannia,' Theatre Quarterly, 7, 28, 1991, pp.369-89 and J Davis \& T C Davis, 'The People of the "People's Theatre": The Social Demography of the Britannia Theatre, Hoxton,' Theatre Survey, 32, 1991, pp.137-65

17 For example, R B Peake's very successful play, 'The Climbing Boy', emphasised the 'lost boy' theme rather than focus on exploitative child labour.

18 Era 4 September 1870

19 Donkeys were commonly referred to as 'Jerusalem canaries', at least by my northLondon family, though I have been unable to trace the origin of the phrase.

20 A similar device, the street urchin commenting on the passing world was used to great effect in her character the City Waif and the songs that went with it.

21 See also 'Astrilly's Goold Fields' and 'Tommy Carr's Adventures in Astrilly, though the latter warns of high prices - 'Sma' beer's ten shilling a quart in Astrilly, O!'

22 Hence the slang for being alone - 'on his Jack Jones'

23 Advert for performance at St James's Hall, Piccadilly, Era 18 June 1871. A similar approach was adopted in a concert in Berwick the song was performed by 'Miss Penelope Pernickity.' Berwick News, 19 November 1872. 
24 Era 16 October 1870 spoke of her 'quaintly dressed old maid' in a performance at the Eastern, Limehouse.

25 Era, 7 January 1872

26 Wingrove 'Reigniting the "Vital Spark", p.92

27 Wingrove, 'Reigniting the "Vital Spark", p. 95

28 The patter that accompanied the song was more equivocal but in the absence of information on performance it is impossible to say what stance she took.

29 The politics of the song is confused. While one verse refers to (suffragette) protests in London, the chorus says, 'my wife's joined the suffragists.'

30 D Taylor, The new police in nineteenth-century England, Manchester University Press, 1997, chap. 4

31 C Pulling, They Were Singing, London, Harrop \& Co., 1952, pp.87-8

32 Era 24 December 1871. Earlier that year at the Alhambra Theatre of Varieties the audience had been regaled with the sight of 'half a dozen dogs being made to "move on" by another dog dressed as a policeman. Era 4 June 1871

33 Review of the 'thrilling sketch, Men and Metal, at the Sebright, 1892. Era, 16 January 1892. See also the 'loud laughter' and 'merriment and derision' that greeted the 'invariably ill-used policeman' at Crystal Palace and the Britannia, respectively. Era 29 December 1894 and 15 January 1898.

34 H R P Gamon, The London Police Court, London, Dent \& Co., 1907, p.40

35 See also C P Cove's 'The Model Peeler', the patter to which makes clear that the so-called model constable accepts bribes, lies in court and does his duty, like a man, with the help of his 'trusty staff'. With the exception of Albert Chevalier's 'The village constable,' which is an out-and-out parody expressed in 'yokel' language, the emphasis is on urban policing. 